\title{
Intellectual Currents and Circulations
}

\author{
Motions of Ideas, Bodies, and Influences in the Pentecostal World
}

The value or social value of an idea is only achieved by circulation. The process of circulation itself does not generate ideas-human brain power does. But without this circulation in seminars, books, journals, and personal interactions among thinkers, the social value itself will not exist. Without the process of circulation, an idea will not generate surplus value, the value over and above its starting point as an outcome of what was invested in it by a single brain.

In this issue, we bring you essays on how theological ideas, viewpoints, influences, and hopes for inclusivity circulate and are transformed contextually in the worlds of theological scholars, textual interpreters, and everyday Christians. Issue 43.2 of Pneuma maps bold stories of the mobility of ideas. We start from the currents of contemporary pentecostal and charismatic interpretation, which flow around and through Acts 8:4-25; move to the sourcing of trinitarian ideas in Jesus's teaching itself; proceed to the circulation of theological influences of Christian Reconstruction and the New Apostolic Reformation between North America and Zambia; and navigate our way into "normative" racialized bodies across Black Pentecostal movements in the United States. From here we shift to the recent currents of Lutheran-Pentecostal ecumenical ideas in Sweden. Finally, we return to a tribute note honoring four past presidents of the Society for Pentecostal Studies (SPS), whose ideas continue to circulate among us, as they soar to heaven on the strong wings of their scholarship and godly leadership.

Circulation and mobility constitute an excellent lens through which to interpret Pentecostalism and the contribution of pentecostal scholarship to a contemporary understanding of the human condition. The pentecostal way of being is "predicated on mobility or, more precisely, circularity."1 Devaka Premawardhana, in his 2018 book Faith in Flux (the winner of the 2021 Pneuma Book Award), artfully used this lens of circulation to map the singular story of the mobility of Makhuwa Pentecostals in the southern African country of

1 Devaka Premawardhana, Faith in Flux: Pentecostalism and Mobility in Rural Mozambique (Philadelphia: University of Pennsylvania Press, 2018), 46. 
Mozambique. Mobility is not only about changes in geographical locations or reach, that is, movement, or finding one's way in institutionalized relationships or networks. It is also about a subject's ability to move spatially and socially in a field of possibilities, intentionally accessing possibilities, appropriating them, and developing the skills to use them to accomplish his or her mission. ${ }^{2}$

We are using this lens of mobility to frame the 2021 SPs Presidential Address, four articles, and the historical note honoring the lives of four SPs Presidents in this issue. Ideas-human lives lived in pursuit of ideas or life of the mindmay be pictured as a flow, as a motility of being. Living lives predicated upon theological ideas or concepts is all about negotiating fluxes and flows. The sustenance of ideas is fundamentally about nurturing their power to float and be accepted, to circulate within a network of relationality. Ideas circulate. A theological idea is an artery, or a vein, or a capillary in a Christian system of scholarly, ecclesial, and public life. For an idea to flow, its power of being must be about motions and movements, overcoming obstacles. The power of the being of an idea is in its circulation. In this issue, we thus point to the sustainability of theological ideas as the circulatory logic of their motion and movement. Circulation is the overarching framework or ideological matrix within which theological ideas happen in Christianity. In these six articles, we get a glimpse of the generation of ideas as a form of spirituality, the practice of initiating something new, the capacity to begin new thought patterns, novel practices, and putting innovative interpretative paradigms into circulation in the pentecostal lifeworld.

In the first article, Martin Mittelstadt's 2021 SPS Presidential Address narrates the history of pentecostal-charismatic reception of Acts 8. In exploring the different ways pentecostal and charismatic believers have received, appropriated, and deployed Acts 8, he demonstrates how its interpretations among the various families of the movement in the United States have been used to reinforce already existing theological ideas and ecclesial practices, often either defining borders of exclusion or breaking them. Mittelstadt finds that "Pentecostals cluster in their respective tribes and use Acts 8 to fortify their beliefs, solidify family identity, branch into new territories, and/or adopt (or dismiss) new affiliates. To do so, these branches of our family focus more or less on various characters and their respective behaviors in the Lukan account. I argue that a pentecostal reception of Acts 8 reveals less 'what Luke says' and more 'what Luke can do for us'" (p. 175). As Mittelstadt traces the currents of the interpretations of Acts 8 , the reader gets the impression that pentecostal-charismatic believers did not

2 Premawardhana, Faith in Flux, 17-18. 
generally put the accent of their interpretations on racial reconciliation or on the ethos of border-breaking. The circulation of the interpretations of Acts 8 moved along such familiar grooves as Spirit baptism, the timing of baptism, power and dominion over territorial spirits, and speaking in tongues. All this led Mittelstadt to conclude that "perhaps the notion of Gospel 'power' needs to include more than personal baptisms of the Spirit, exorcisms, and squashing magicians. Is it time to understand Samaria and Pentecost as exorcisms of demonic exclusivity?" (p. 198).

The second article maps the circulation of a central idea of Christian faiththe divine personhood of Jesus and the Spirit leading to the doctrine of the Trinity-as sourcing historically from Jesus himself, as witnessed in the canonical Gospels. In our second article, Craig Keener insists that materials that source this idea go back to the earliest period of the Christian faith, during Jesus's ministry and post-resurrection appearances. He argues that Jesus is the direct source of the disciples and biblical authors' belief that he is divine and the understanding that the Spirit is distinct from the Father. "Jesus's postresurrection (and possibly some late pre-resurrection) teaching about himself and the Spirit offers a more plausible explanation for the early and widespread appearance of such motifs in early Christianity" (p. 211). Keener, in his usual manner, meticulously traces the circulation of textual evidence and inferences from the early days of Christianity to support his claim, which is contrary to the prevailing position in many academic circles.

There is a two-thousand-year gap between the type of circulation of theological ideas that caught the interest of Keener, a New Testament scholar, and the type that captures the mind of anthropologist Naomi Haynes, of the University of Edinburgh, who has travelled across continents to perform her mixedmethods research on Christian nationalism in Zambia. She deftly explores the circulation of theological influences between the United States and the southern African nation of Zambia in the twenty-first century. She traces how theologies of Christian Reconstruction and New Apostolic Reformation (NAR) flowing in North America influenced the conceptualization of contemporary Christian nationalism in Zambia. Haynes is careful to show that, though the Zambian Pentecostals who advocate for a form of Christian nationalism have drawn from North American theologies, they are themselves creative and mindful enough to adapt them to fit not only their distinct national Christian sensibility but also the particular developmental needs of their country. "While the authors examined here have clearly drawn on the ideas of Christian Reconstruction and NAR in developing their visions of what it means for Zambia to be a Christian nation, it is equally apparent that they have modified these ideas to reflect local perspectives and concerns" (p. 229). 
The fourth article investigates the circulation of black and white bodies in selected contexts of pentecostal-charismatic churches in the United States. The construction of the white male body as the "normative" body in Christian theology, the assumed normal anthropological context for theological ideas, served to inhibit the free circulation of bodies in the churches. Bodies that did not conform to this dominant image were either marginalized, strategically opposed, denigrated, or excluded from positions of power or authority. In spite of the long history of the worrisome and racist construction of "normative" body, Joel Daniels argues that there are resources within pentecostal theology to address and correct the problem. Pentecostal theology, he opines, "has the resources to transgress these myopic confines imposed on the body, freeing the body through sound and movement rather than adhering to static categorization" (p. 233).

Cristina Grenholm, Johannes Habib Zeiler, and Ulrik Josefsson take us to a different form of circulation of bodies. In their essay on ecumenical dialogue in Sweden, they demonstrate how church bodies (Lutheran and pentecostal) and bodies of ideas (denominational theological concepts and doctrines) weigh on each other over years of efforts to narrow the divisive differences in the body of Christ. Their discussions of the history and movements in the dialogue are framed by the growing theoretical field of receptive ecumenism. The study concludes that "more consensus is reached in areas of societal ministry and advocacy than concerning doctrinal issues. The analysis shows deep ecumenical ambitions built on trust but also reveals some difficulties on the path toward Christian unity" (p. 250).

The final essay is a fitting way to end the run of the set of six articles in a tribute note honoring four special contributors to pentecostal studies who went home to the presence of the Lord in 2019-2020. Kimberly Alexander provides brief and lucid accounts of the life and scholarship of these four past SPS Presidents: Vinson Synan, who was the last living of the Society's three founders; Leonard Lovett, the pathfinding and prophetic African-American pentecostal scholar and leader; and two seminal historians, Edith Blumhofer and Donald Dayton. She gives us a compelling account of how their lives and ideas circulated within the SPS and left great legacies for all those who came after them. Alexander honors them by reminding us that " $[\mathrm{i}] \mathrm{n}$ examining the contributions of this diverse group of leaders and scholars, it seems clear that they represent both the best that SPS has been and all that it promises to be: vision, prophetic engagement, academic rigor, and inclusivity. Each brought discerning discoveries to the scholarly conversation" (p. 293).

The 2021 SPs Presidential Address, the four articles, and the historical tribute are each an indication or symbol of instances, moments, or sedimenta- 
tions of circulation or mobility. All six articles are references to the dialectic of movements of ideas, the energy of engaging the pentecostal lifeworld, and the patience of trafficking with the faith that seeks understanding and reconciliation. While each puts us into the ageless circulation of ideas, collectively they have augmented the surplus value of pentecostal studies by enlarging the shores of the ever-flowing river of knowledge. It bears repeating what we stated at the beginning of this editorial: The pentecostal way of being is "predicated on mobility or, more precisely, circularity."3 Ideas, good theological ideas and influences, constitute an irreplaceable anchor and vitality of the circulation processes of our vast religious tradition.

Nimi Wariboko and L. William Oliverio, Jr.

3 Premawardhana, Faith in Flux, 46. 